\title{
Health Services Research in Psoriasis - The German Approach
}

\author{
M. Augustin ${ }^{a} \quad$ K. Reich ${ }^{b} \quad$ M. Reusch ${ }^{c} \quad$ T. Luger ${ }^{d} \quad$ N. Franzke ${ }^{a} \quad$ I. Schäfer ${ }^{a}$ \\ S.J. Rustenbach ${ }^{a}$ M.A. Radtke ${ }^{a}$ \\ a Health Economics and QoL Research Group, German Centre for Health Services Research in Dermatology \\ CVderm, Department of Dermatology, University Clinics of Hamburg, ${ }^{\mathrm{b}}$ Dermatologikum and ${ }^{\mathrm{C}}$ Dermatologic \\ Practice, Hamburg, and ${ }^{\mathrm{d}}$ Department of Dermatology, University Clinics of Münster, Münster, Germany
}

\section{Key Words}

Psoriasis $\cdot$ Health care guidelines $\cdot$ Health care provision

Beyond clinical research, the health care provision of psoriasis has gained substantial interest in many countries. On the one hand, data on the postregistration use of antipsoriatic drugs are gained in non-interventional studies like patient registries. On the other hand, research activities focus on the questions of quality, need and costs for health care provision [1]. Altogether, these research fields are summarized as 'health services research'. This article intends to describe the German approach of health services research in psoriasis.

\section{Need for Health Services Research in Germany}

Reduced allocation of resources to the health care system in recent years has increased the need for balanced distribution and efficient use of the available resources $[2,3]$. Appropriate allocation of resources requires knowledge of the real state of health services provision. This knowledge can be acquired using instruments of health services research.

In this context the German National Advisory Council on the Assessment of Developments in the Health Care System, the German Medical Association, the health insurance funds and other parties involved in the health care sector have realized the need to obtain specific data on health services provision. The task of health services research is to investigate the reality of health services provision under everyday conditions (German Medical Association 2005). Health services research has established itself as the third pillar of health research - along with biomedical basic research and clinical research. In order to provide a picture of the state of health services provision in Germany, it is necessary to obtain sufficient upto-date national data on the German health care system. Though the development of effective health services research is now regarded as essential, our knowledge of the state of health services provision in Germany is, in some cases, still only rudimentary, even in the case of some of the most common diseases. This is especially true for skin diseases.

\section{Action Plan: The National Centre for Health Services Research in Dermatology - CVderm}

The German Society for Dermatology and Venereology (DDG) and the German Board of office-based dermatologists (BVDD) recognized this situation and, in cooperation with the Chair of Health Economics and Quality of Life Research of the University Hospital Hamburg-Eppendorf, set up a National Centre for Health Ser-

\section{KARGER}

Fax +4161306 1234 E-Mail karger@karger.ch www.karger.com
(C) 2009 S. Karger AG, Basel

$1018-8665 / 09 / 2184-0293 \$ 26.00 / 0$

Accessible online at:

www.karger.com/drm
Prof. Dr. Matthias Augustin

German Centre for Health Services Research in Dermatology CVderm

Department of Dermatology, University Clinics of Hamburg

Martinistrasse 52, DE-20246 Hamburg (Germany)

Tel. +49 4042803 5428, Fax +49 4042803 5348, E-Mail m.augustin@derma.de 


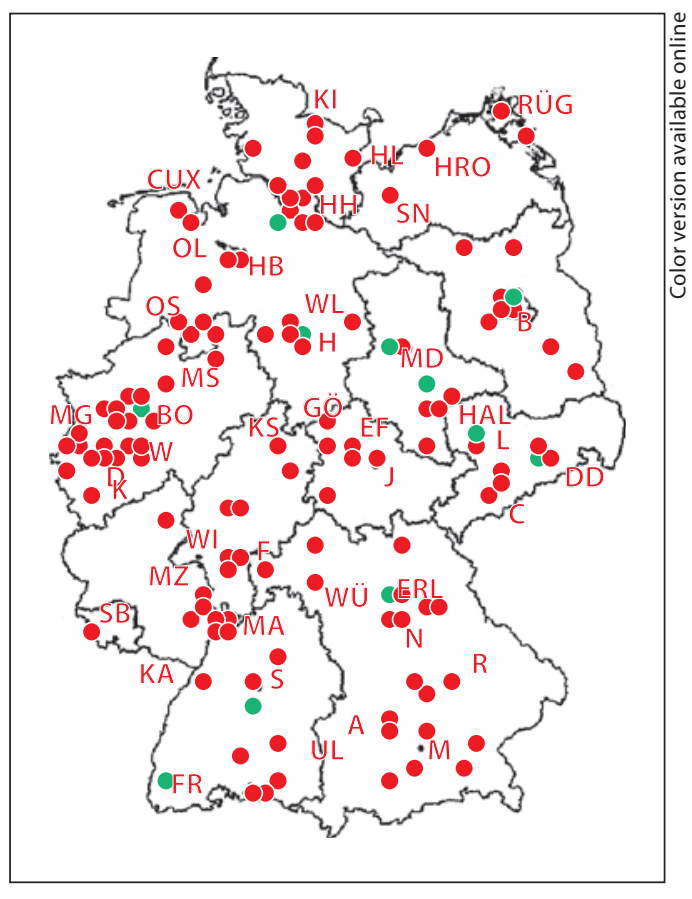

Fig. 1. Centres participating in the PsoHealth national health care study [23].

vices Research in Dermatology (CVderm). This centre documents the health services research activities being conducted at present in Germany in the field of dermatology and allergology and advises research groups on the performance of studies on health services provision. In addition, CVderm performs studies of its own on health economics, patient benefit, the epidemiology of important diseases and quality of care in dermatology and allergology.

The first programme to monitor the quality of health care in dermatology focused on psoriasis.

\section{Health Services Research in Psoriasis}

Psoriasis is a common disease that is present in approximately $2.5 \%$ of German adults, in about 2.0 million people in Germany annually $[4,5]$. It affects $1-3 \%$ of the population worldwide [6]. Recent data on the care of this disease show that psoriasis is of considerable socio-economic [7-11], social [12-17] and medical importance [1821]. The scientifically recognized standard of medical care is defined by the German national treatment guideline [22]. This was developed as an S3 guideline (guideline of the highest methodological level) and has been adopted by the Association of Scientific Medical Societies in Germany. In Germany psoriasis is treated largely by office-based dermatologists and in severer cases also in dermatology outpatient clinics and hospital wards [23]. Milder cases, in particular, are also treated to some extent by general practitioners and paediatricians, while patients with comorbidities such as psoriatic arthritis are also treated by internists, rheumatologists, radiologists and orthopaedic surgeons.

As a consequence of early results obtained in studies on health services provision conducted between 2004 and 2006, in their capacity as representatives of the German dermatological fraternity, the DDG and the BVDD initiated an action programme aimed at further improving the care of patients with psoriasis. This programme includes the introduction of a long-term patient registry, the initiation of a series of studies on psoriasis care, the implementation of measures designed to improve quality, the establishment of regional psoriasis networks, and cooperation with self-help organizations and patient groups. These activities are described in the following.

Concerning psoriasis, CVderm has participated in a number of projects on health services provision in which the characteristics of this disease that are relevant to health care are evaluated:

- Quality of life: a number of German studies conducted by CVderm and external working groups have assessed the extent to which psoriasis impairs the patient's quality of life, i.e. the disease burden of psoriasis [24-27].

- Disease costs: two studies gained data on disease costs and use of resources in psoriasis $[7,8]$.

- Quality of health care: in 'PsoHealth', a series of national studies were conducted in dermatology practices and hospital dermatology departments in order to generate data on quality of health care, therapeutic benefit to the patient, and compliance of care with guidelines (fig. 1) [23]. Additional studies on the quality of health care in psoriasis are being undertaken as part of the 'PsoReal' project with the aid of self-help organizations, as part of the 'PsoPharm' project with the aid of a national pharmacy network, and as part of the 'PsoCare' project in the form of a study of secondary data obtained from health insurance funds. In the 'PsoWeb' project, health care data are obtained via the internet. The various projects are designed to obtain data on psoriasis patients from a number of different settings so as to minimize selection bias associated with the individual settings. 
Table 1. Profile of psoriasis in Germany

\begin{tabular}{|c|c|c|}
\hline Marker & Size & Source \\
\hline Prevalence in adult population & $\begin{array}{l}2.1 \% \text { point prevalence } \\
2.5 \% \text { 1-year prevalence } \\
=2.0 \text { million persons }\end{array}$ & $\begin{array}{l}\text { Schäfer et al. [28], } 2008 \\
\text { Augustin et al. [30], } 2008\end{array}$ \\
\hline $\begin{array}{l}\text { Prevalence of psoriatic arthritis } \\
\text { within psoriasis of the skin }\end{array}$ & $20.6 \%$ & Reich et al. [31], 2008 \\
\hline Severity of disease & $\begin{array}{l}\text { Average PASI } 10.1 \\
\text { PASI }>10: 39.4 \% \\
\text { PASI }>20: 11.6 \%\end{array}$ & Augustin et al. [23], 2008 \\
\hline Quality of life & $\begin{array}{l}\text { Average DLQI } 7.5 \\
\text { DLQI >1: } 81.2 \% \\
\text { DLQI }>5: 50.9 \% \\
\text { DLQI }>10: 28.2 \%\end{array}$ & \\
\hline $\begin{array}{l}\text { Previous systemic therapy } \\
\text { received }\end{array}$ & $\begin{array}{l}\text { All patients: } 50.7 \% \\
\text { Severe psoriasis: } 66.7 \% \\
\text { Psoriatic arthritis } 74.5 \%\end{array}$ & \\
\hline $\begin{array}{l}\text { Average annual cost in } \\
\text { moderate to severe psoriasis } \\
\text { (EUR) }\end{array}$ & $\begin{array}{l}\text { 6,709 per patient, including: } \\
\text { SHI: } 4,365 \\
\text { SPI: } 239 \\
\text { Patients: } 794 \\
\text { Indirect costs: } 1,310\end{array}$ & Sohn et al. [7], 2006 \\
\hline $\begin{array}{l}\text { Costs according to treatment } \\
\text { status (EUR) }\end{array}$ & $\begin{array}{l}\text { No systemic therapy: } 4,088 \\
\text { Systemic therapy: } 7,148 \\
\text { High-need: } 8,831\end{array}$ & \\
\hline $\begin{array}{l}\text { Profile of 'high-need' patients } \\
\text { (vs. all patients) }\end{array}$ & $\begin{array}{l}\text { Proportion: } 17.2 \% \\
\text { PASI } 22.1 \text {, DLQI } 13.9 \text {, mean annual cost } 8,800 \text { EUR } \\
\text { Days absent from work: } 11.7 \text { vs. } 3.9 \\
\text { Inpatient treatment: } 50.4 \text { vs. } 21.1 \% \\
\text { Impairment of QoL: DLQI } 12.5 \text { vs. } 8.6\end{array}$ & $\begin{array}{l}\text { Sohn et al. [7], } 2006 \\
\text { Augustin et al. [32], } 2008\end{array}$ \\
\hline
\end{tabular}

PASI = Psoriasis Area and Severity Index; DLQI = Dermatology Life Quality Index; SHI = statutory health care insurance; SPI = statutory pension insurance; QoL = quality of life.

- Epidemiology: another series of studies ('PsoEpi') is concerned with the epidemiology of psoriasis and is designed to acquire epidemiological data on the prevalence and care of the disease. In the first study in this series (PsoEpi 1), data from 48,665 adults who had undergone occupational screening for skin cancer were examined [28], followed by a second study on a further 30,000 persons.

- Patient registry: in the German psoriasis registry 'PsoBest', the long-term outcomes of psoriasis therapy are being studied for the first time in a large number of German patients. Only in this way can information relevant to care of the disease be obtained under conditions of clinical practice so as to permit optimization of therapy. This registry is strongly affiliated to the European psoriasis registry network 'Psonet' [29].

\section{Epidemiology and Quality of Psoriasis Care in Germany}

In order to provide a picture of the state of psoriasis care in Germany, CVderm commissioned a team of experts to draw up a set of quality indicators. When considered in association with key data on the prevalence and treatment of psoriasis, these quality indicators provide a long-term picture of psoriasis care. In accordance with the German Social Code (Sozialgesetzbuch V), the procedural rules of the Federal Joint Committee (Gemeinsamer Bundesausschuss) and the methods paper of the Institute for Quality and Efficiency in Health Care (Institut für Qualität und Wirtschaftlichkeit im Gesundheitswesen), particular emphasis was placed on measures of patient benefit. 


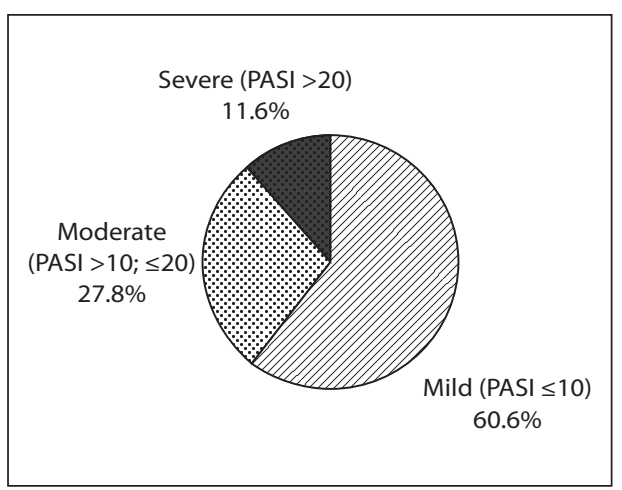

Fig. 2. Distribution of clinical severity in psoriasis patients in Germany $(\mathrm{n}=2,009)$ [23].

The current profile of the state of psoriasis care in Germany includes the following features (table 1).

\section{Prevalence}

According to up-to-date study data from 2007, psoriasis has a point prevalence of $2.1 \%$ in adults in Germany [28]. These data were obtained in a population of approximately 48,000 working adults of all occupations. Comparisons with sociodemographic data from the Federal Statistical Office (Statistisches Bundesamt) show that this sample is more or less representative of the overall adult population of Germany. Based on this it can be concluded that in the cross-section, on average approximately 1.7 million people in Germany suffer from psoriasis. Data from health insurances on 1.6 million insured persons indicate that the 1-year prevalence of psoriasis is $2.5 \%$, which suggests that 2 million Germans are affected per year.

Psoriatic arthritis was found to be present in $20.6 \%$ of all psoriasis patients undergoing dermatological treatment [31]. Because of its frequency, the high burden of disease and the need of systemic treatment, psoriatic arthritis is also of great medical and socio-economic importance. When different age groups are considered, the highest prevalence of psoriasis is found between the ages of 20 and 50 years [28]. Approximately $80 \%$ of patients are less than 65 years old and thus of employable age. Approximately $50 \%$ are less than 45 years old and thus at an age when they may be planning and starting families.

The sex distribution of psoriasis in epidemiological studies and also in studies on health services provision is about $55 \%$ male and $45 \%$ female patients $[23,33]$.

Another medically and socio-economically important fact is that psoriasis patients live with their disease for periods of up to several decades. Thus, in the patients participating in the PsoHealth study $(\mathrm{n}=2,009)$, the mean duration of the disease was found to be 21 years, and during a high proportion of this time the disease was in a phase in which treatment was required [23]. The tendency of psoriasis and psoriatic arthritis to become chronic represents both a medical and health-economic challenge. It is also important in terms of the need for long-term management and in terms of patients' longterm outlook. This time frame must be taken into account when assessing the potential risk-benefit relationship of treatment.

In summary, in epidemiological terms psoriasis is a common and chronic disease in Germany that affects a broad age range. In combination with psoriatic arthritis and other comorbidities, it poses an interdisciplinary challenge [34]. The need for care is especially high in patients with moderate to severe disease.

\section{Severity of Psoriasis}

The provision of adequate care for psoriasis patients depends to a large extent on a precise knowledge of the range of severity of the disease and the range of the burden imposed by the disease.

In the PsoHealth study, which was conducted in 2007, $11.6 \%$ of patients were found to have very severe psoriasis (Psoriasis Area and Severity Index, PASI, above 20) and approximately $39.4 \%$ to have moderate to severe psoriasis (PASI 10-20; fig. 2) [23]. These patients are in particular need of medical care, generally in the form of UV therapy and systemic treatments in combination with topical measures.

In the same study, the proportion of patients with impaired quality of life was used as another measure of the severity of the disease. Internationally, the most commonly used measure of disease-specific quality of life is the DLQI (Dermatology Life Quality Index), a global measure made up of 10 items that is expressed as a score ranging from 0 (no impairment of quality of life) to 30 (maximum impairment) [35]. Values above 10 are regarded as indicating severe to very severe impairment of quality of life [36]. On the basis of the DLQI approximately $28.2 \%$ of patients were found to have severe to very severe impairment of quality of life. This also imposes a considerable need for care (fig. 2, 3).

Preliminary analyses showed little or no correlation between present quality of life and present degree of clinical severity [37]. As far as the requirement for health provision is concerned, a distinction must therefore be drawn between clinical severity and severity in terms of impair- 
ment of quality of life. Accordingly, as defined in the 'rule of tens' [38], both parameters indicate patients with severe disease.

\section{Costs of Psoriasis}

Another important measure in terms of health services provision is the cost of psoriasis. Two earlier largescale national studies on the costs attributable to psoriasis demonstrated beyond doubt that psoriasis is an economically important disease in Germany $[7,8]$. Depending on severity and treatment given, the annual cost per patient varied between 2,000 and 9,000 EUR. In the study by Sohn et al. [7], the average annual cost of moderately severe to severe psoriasis was found to be 6,600 EUR per patient (table 1). Of this amount, the greatest part was borne by statutory health care insurance $(4,000$ EUR), followed by statutory pension insurance (1,200 EUR) and the patients themselves (900 EUR). The average annual indirect costs of psoriasis in Germany amounted to 1,200 EUR.

The average total cost was lowest, at about 4,000 EUR, in patients who received only local therapy, higher, at about 7,000 EUR, in patients who received systemic therapy, and highest, at about 9,000 EUR, in high-need patients. The last category included patients in whom conventional systemic therapies no longer brought a response, were contra-indicated or had been stopped because of adverse reactions.

In summary, therefore, psoriasis must be regarded as an economically relevant disease.

\section{Range of Treatments Available for Psoriasis}

The necessary treatment for every type and every degree of severity of psoriasis is available in Germany. The scientifically recognized standard of care was established in 2006 by the $\mathrm{S} 3$ guideline on psoriasis therapy (AWMF 2006) [22]. In theory, the cost of any treatment option for psoriasis that is listed as useful in the guideline is covered by statutory health insurance. In practice, however, in recent years there have been some obstacles to the prescription of drugs for psoriasis.

In the field of UV therapies, only some of the medically useful options are covered by statutory health insurance. Over the past few years the absence of recognition of ambulant balneophototherapy has created a gap with regard to both photo-brine therapy and bath-PUVA therapy. Therefore, despite having been shown to be effective on the basis of evidence-based criteria and being recommended in the guideline, these therapies have to date been used only in the inpatient setting and in self-paying

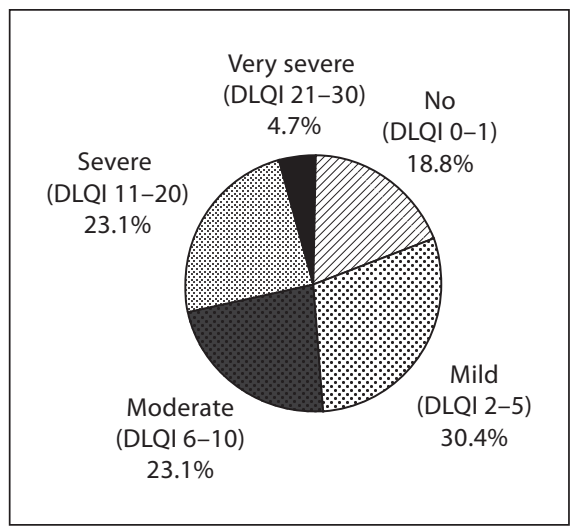

Fig. 3. Distribution of quality of life impairment in psoriasis patients in Germany $(n=2,009)$ [23].

patients. As a result of the favourable assessment of ambulant balneophototherapy by the Federal Joint Committee (Gemeinsamer Bundesausschuss) on November 15, 2007 , the availability of this treatment option in the ambulant setting may improve, provided that there are sufficient reasons for making it available on the basis of evidence-based medicine.

\section{Quality of Psoriasis Care - Current Study Data}

In 2005, in the first national study on the care of psoriasis in Germany [32], it was found that in a proportion of psoriasis patients, in particular those with moderately severe to severe psoriasis, the available range of antipsoriatics was either not being used or not being used to a sufficient extent. For example, the proportion of patients with psoriasis of any degree of severity who had received systemic therapeutic agents at any time in the preceding 5 years was only $33 \%$. Even in patients with severe psoriasis (PASI over 20 corresponding to $17.2 \%$ of patients), the proportion who had received systemic antipsoriatics was only $45 \%$. Similarly, only about $50 \%$ of patients with psoriatic arthritis had received systemic drugs. By contrast, almost all the patients had received topically administered drugs and about $65 \%$ had received UV therapies. At the time the study was performed, biological agents had not yet been approved for use.

From these data, it was concluded that in the year 2005 there was significant under provision of systemic drugs to patients with moderately severe to severe psoriasis.

In the summer of 2007 , the study was repeated as a 'National study on psoriasis care - PsoHealth' [23]. In 


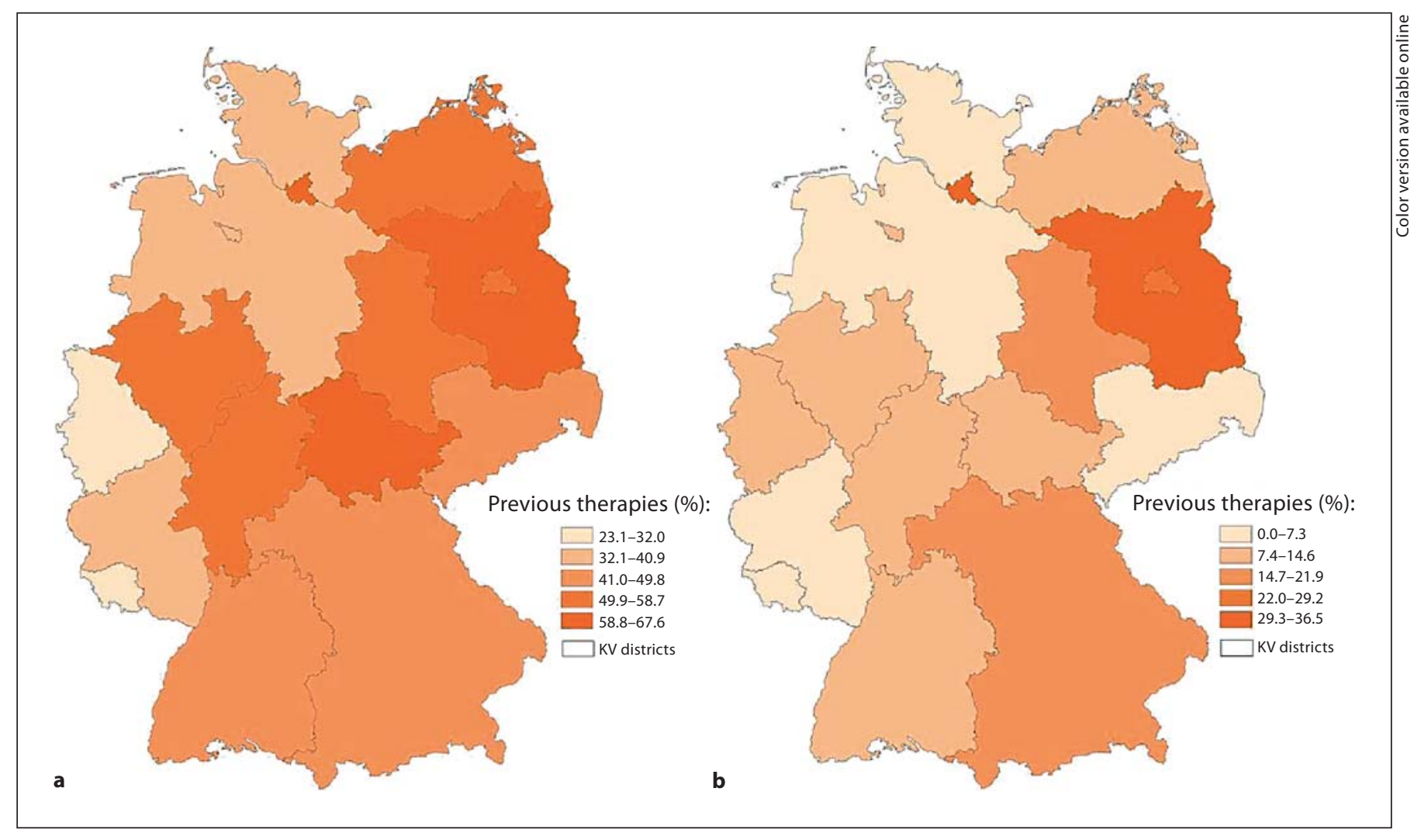

Fig. 4. Inhomogeneity of health provision in Germany: proportion of patients who had previous treatments with conventional systemic (a) and biological agents (b). PsoHealth study, 2007 ( $n=2,009$ patients); source: CVderm 2007; cartography and design: Jobst Augustin. KV = Kassenärztliche Vereinigung (panel doctors' association).

this study performed in over 2,000 patients from 150 participating centres, it was found that the proportion of patients who had received systemic therapy had risen by $10-30 \%$ compared to the previous study and that more than $15 \%$ of patients had now received biological agents, while at the same time there had been a substantial reduction in the proportion of patients whose quality of life was severely impaired (table 2).

There were significant geographical differences in psoriasis health provision (fig. 3) which deserve an explanation and foremost provide a starting point for further improvements.

As the PsoHealth 2007 study was performed at the time of implementation of the $\mathrm{S} 3$ guideline on psoriasis therapy [22], its results can be seen as indicators of the results of the early implementation phase of the guideline. For this reason, the PsoHealth study was designed partly as an 'implementation study' to assess compliance with the guideline. To this end, members of the guideline committee, with input from the AWMF and representa-
Table 2. Indicators of quality of care in psoriasis: comparison 2005-2007 [23]

\begin{tabular}{|c|c|c|c|}
\hline Parameter & 2005 & 2007 & $\begin{array}{l}\text { Quality } \\
\text { of care }\end{array}$ \\
\hline Mean severity of psoriasis (PASI) & 12.0 & 10.1 & + \\
\hline Mean quality of life of patients (DLQI) & 8.6 & 7.5 & + \\
\hline $\begin{array}{l}\text { Proportion of patients with severe } \\
\text { psoriasis }(\text { PASI }>20)\end{array}$ & 17.3 & 11.6 & + \\
\hline $\begin{array}{l}\text { Proportion of patients with severely } \\
\text { impaired quality of life (DLQI }>10)\end{array}$ & 34.1 & 28.2 & + \\
\hline $\begin{array}{l}\text { Proportion of patients with preceding } \\
\text { systemic therapy }\end{array}$ & 33.0 & 50.7 & + \\
\hline $\begin{array}{l}\text { Proportion of patients with PASI }>20 \\
\text { with preceding systemic therapy }\end{array}$ & 45.4 & 66.7 & + \\
\hline $\begin{array}{l}\text { Proportion of patients with inpatient } \\
\text { therapy in the last } 12 \text { months }\end{array}$ & 23.1 & 20.1 & + \\
\hline Mean number of days away from work & 3.9 & 3.4 & + \\
\hline
\end{tabular}

2005: National study on quality of psoriasis care; 2007: National study on quality of psoriasis care [23]; + = indication of improved quality of health care. 
Table 3. Current studies on psoriasis care in Germany performed by the CVderm

\begin{tabular}{|c|c|c|c|c|}
\hline Study & Title & Area & Number & Objective \\
\hline PsoEpi & Epidemiology of psoriasis in Germany & Epidemiology & $\begin{array}{l}78,000 \\
\text { healthy } \\
\text { adults }\end{array}$ & $\begin{array}{l}\text { To estimate the prevalence of psoriasis in the } \\
\text { German working population by skin-screening }\end{array}$ \\
\hline PsoCare & $\begin{array}{l}\text { Study on psoriasis care in } 1.9 \text { million } \\
\text { people with statutory health insurance }\end{array}$ & Epidemiology & 33,981 & $\begin{array}{l}\text { To identify markers of quality of care in data sets } \\
\text { from statutory health insurance funds }\end{array}$ \\
\hline PsoKid & Epidemiology of psoriasis in children & Epidemiology & $\begin{array}{l}1.6 \text { million } \\
\text { insured } \\
\text { persons }\end{array}$ & $\begin{array}{l}\text { To gain data on the prevalence of psoriasis and } \\
\text { psoriatic arthritis in patients of the statutory health } \\
\text { insurances }\end{array}$ \\
\hline PsoBest & German psoriasis register $2007-2016$ & Patient registry & 3,500 & $\begin{array}{l}\text { To determine long-term outcomes in } 3,500 \text { psoriasis } \\
\text { patients receiving systemic or biological therapy, } \\
\text { observed over } 5 \text { years }\end{array}$ \\
\hline PsoHealth & National study on psoriasis care & Quality of care & 2,009 & $\begin{array}{l}\text { To obtain data on quality of care and guideline- } \\
\text { compliant care in dermatology practices and hospital } \\
\text { dermatology departments }\end{array}$ \\
\hline PsoReal & $\begin{array}{l}\text { Study on psoriasis care in patients in } \\
\text { self-help organizations }\end{array}$ & Quality of care & 2,449 & $\begin{array}{l}\text { To obtain data on quality of care and therapeutic } \\
\text { benefit in patients in self-help organizations }\end{array}$ \\
\hline PsoNail & $\begin{array}{l}\text { Study on quality of life and health } \\
\text { care in nail psoriasis }\end{array}$ & Quality of care & 400 & $\begin{array}{l}\text { To get insight into quality of life and health care in } \\
\text { nail psoriasis }\end{array}$ \\
\hline PsoPharm & $\begin{array}{l}\text { Study on psoriasis care in pharmacy } \\
\text { network } 2008\end{array}$ & Quality of care & 500 & $\begin{array}{l}\text { To obtain data on quality of care and therapeutic } \\
\text { benefit in patients in a Germany-wide network of } \\
\text { pharmacies }\end{array}$ \\
\hline PsoWeb & $\begin{array}{l}\text { Study on psoriasis care performed } \\
\text { via the Internet }\end{array}$ & Quality of care & 2,500 & $\begin{array}{l}\text { To obtain data on quality of care and therapeutic } \\
\text { benefit in patients via Internet portals }\end{array}$ \\
\hline PsoMetrics & $\begin{array}{l}\text { Outcome measurements and therapeutic } \\
\text { objectives in the treatment of psoriasis }\end{array}$ & $\begin{array}{l}\text { Quality of outcome } \\
\text { measurements }\end{array}$ & 3,000 & $\begin{array}{l}\text { To introduce and evaluate standardized methods of } \\
\text { determining outcomes in psoriasis; to establish a } \\
\text { 'measurement culture' }\end{array}$ \\
\hline PsoPASI & $\begin{array}{l}\text { Significance and validity of PASI } \\
\text { from the patient's perspective }\end{array}$ & $\begin{array}{l}\text { Quality of outcome } \\
\text { measurements }\end{array}$ & 550 & $\begin{array}{l}\text { To evaluate the relevance, significance and validity } \\
\text { of PASI } 75 \text { and PASI } 90 \text { to the patient }\end{array}$ \\
\hline PsoNet & $\begin{array}{l}\text { Coordination of regional psoriasis } \\
\text { networks in Germany }\end{array}$ & $\begin{array}{l}\text { Improvement of } \\
\text { health care }\end{array}$ & & $\begin{array}{l}\text { To initiate and coordinate regional networking } \\
\text { activities on psoriasis care; better and more efficient } \\
\text { health care for psoriasis on a national level }\end{array}$ \\
\hline
\end{tabular}

tives of patients, drew up a set of 'indicators of guidelinecompliant therapy'. These are being assessed at present. According to an analysis of the data obtained to date, a substantial, though not completely satisfactory, proportion of psoriasis patients are being treated in accordance with the S3 guideline.

In summary, the results of the national health care study of 2007 suggest that the quality of care of psoriasis in Germany has undergone a significant improvement in recent years and that the efforts of the dermatological fraternity in this regard are now bearing their first tangible fruit.

\section{Further Plans to Improve the Quality of Psoriasis Care}

Following an analysis of the results of the health care studies performed in dermatology practices, a number of additional studies aimed at obtaining further information on the care of psoriasis in other settings were initiated (table 3).

\section{Improved Care via PsoNet - Regional Psoriasis}

Networks in Germany

Based on the available data on psoriasis care, the DDG and the BVDD, in cooperation with the CVderm, devel- 
oped an action plan designed to improve psoriasis care in Germany. This plan calls for the establishment of decentralized regional psoriasis networks in order to improve quality of care.

In the 'PsoNet' project [39], these networks are coordinated and evaluated throughout Germany. The quality criteria of the regional networks were established by the German Dermatological Academy (Deutsche Dermatologische Akademie) in cooperation with CVderm and its scientific committee. Seventeen regional psoriasis networks have been established to date, and more are to be established in the coming months. The task of the psoriasis networks is to bring together those dermatologists and specialists from other disciplines who have special knowledge of and a particular interest in psoriasis therapy.

\section{Developing a 'Measurement Culture' - PsoMetrics}

The objective measurement of treatment outcomes is hugely important for the implementation and subsequent evaluation of guideline-compliant care [40, 41]. As part of the 'PsoMetrics' project series, a uniform national system of determining outcomes in psoriasis has now been started. Essential basic assessment instruments such as PASI (Psoriasis Area and Severity Index), DLQI and Patient Benefit Index are made available free of cost to all care-providing dermatologists. In addition, basic information on measurement of outcome parameters is provided via the 112 quality circles of general practitioners in Germany, while regular instruction on scoring is provided at congresses and training events for dermatologists. One of the basic objectives of the PsoMetrics project is to communicate the need for a 'measurement culture' in psoriasis care. Closely related to this project is the need - in the treatment of psoriasis as in that of other skin diseases - to establish a predefined set of therapeutic objectives. These are based firstly on the S3 guideline and secondly on the individual preference of the patient. With the aid of standardized outcome instruments, patients can easily be assessed in the office setting to determine whether their therapeutic outcomes have been achieved [33].

By reference to the $\mathrm{S} 3$ guideline, by establishing therapeutic objectives and by systematic measurement, quality of care can be continuously improved.

\section{Outlook}

Over a period of less than 2 years, health services research activities associated with the CVderm, the German competence centre for health services research in dermatology, have significantly extended our knowledge of psoriasis care in Germany. The data obtained have served as a stimulus not only to further studies, but also to the introduction of measures to improve psoriasis care. An initial assessment undertaken after only 2 years suggests that a substantial improvement in psoriasis care has already been achieved.

Over the next few years the activities that have been initiated to date, in particular the development of regional psoriasis networks, will be intensified. As all measures are accompanied by quality management procedures and quality assessments, activities can be efficiently controlled. Independently of any governmental or ministerial support, the DDG and the Professional Association of German Dermatologists have thus developed a novel concept for improving the care of psoriasis patients.

\section{References}

1 Nijsten Z, Wakkee M: Psocare: Italy shows the way in postmarketing studies. Dermatology 2008;217:362-364.

-2 Schmitt J, Meurer M, Klon M, Frick KD: Assessment of health state utilities of controlled and uncontrolled psoriasis and atopic eczema: a population-based study. Br J Dermatol 2008;158:351-359.

-3 Russell LB, Gold MR, Siegel JE, Daniels N, Weinstein MC: The role of cost-effectiveness analysis in health and medicine. Panel on Cost-Effectiveness in Health and Medicine. JAMA 1996;276:1172-1177.

\footnotetext{
4 Schaefer I, Zimmer L, Rustenbach SJ, Augustin M: Prevalence of skin diseases in a cohort of 48,665 employees in Germany. Dermatology 2008;217:169-172.

5 Radtke MA, Augustin M: Economic considerations in psoriasis management. Clin Dermatol 2008;26:424-431.

6 Greaves MW, Weinstein GD: Treatment of psoriasis. N Engl J Med 1995;332:581-588.

7 Sohn S, Schöffski O, Prinz K, Schubert E, Waldorf K, Augustin M: Cost of moderate to severe plaque psoriasis in Germany: a multicenter cost-of-illness study. Dermatology 2006;212:137-144.
}

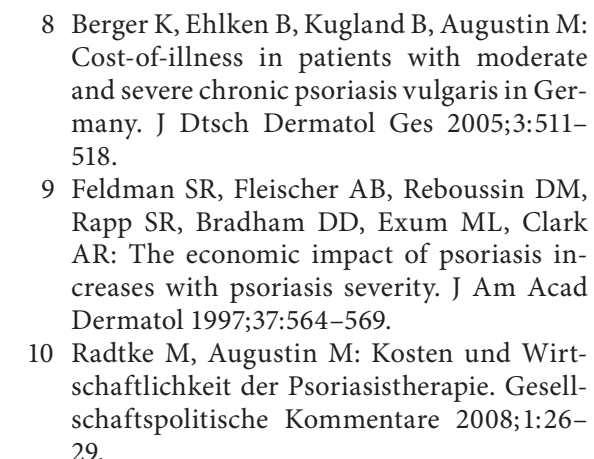
Cost-of-illness in patients with moderate and severe chronic psoriasis vulgaris in Germany. J Dtsch Dermatol Ges 2005;3:511518. creases with psoriasis severity. J Am Acad Dermatol 1997;37:564-569. schaftlichkeit der Psoriasistherapie. Gesell29. 
-11 Heinen-Kammerer T, Daniel D, Stratmann L, Rychlik R, Boehncke WH: Cost-effectiveness of psoriasis therapy with etanercept in Germany. J Dtsch Dermatol Ges 2007;5:762768.

12 Finlay AY, Coles EC: The effects of severe psoriasis on the quality of life of 369 patients. Br J Dermatol 1995;132:236-244.

13 Fried RG, Friedman S, Paradis C, Hatch M, Lynfield Y, Duncanson C, Shalita A: Trivial or terrible? The psychological impact of psoriasis. Int J Dermatol 1995;34:101-105.

-14 Delfino M, Holt EW, Taylor CR, Wittenberg E, Qureshi AA: Willingness-to-pay stated preferences for 8 health-related quality-oflife domains in psoriasis: a pilot study. J Am Acad Dermatol 2008;59:439-447.

-15 Dubertret L, Mrowietz U, Ranki A, van de Kerkhof PC, Chimenti S, Lotti T, Schäfer G; EUROPSO Patient Survey Group: European patient perspectives on the impact of psoriasis: the EUROPSO patient membership survey. Br J Dermatol 2006;155:729-736.

-16 Krueger G, Koo J, Lebwohl M, Menter A, Stern RS, Rolstad T: The impact of psoriasis on quality of life: results of a 1998 National Psoriasis Foundation patient-membership survey. Arch Dermatol 2001;137:280-284

-17 Zachariae R, Zachariae H, Blomqvist K, Davidsson S, Molin L, Mork C, Sigurgeirsson B: Quality of life in 6,497 Nordic patients with psoriasis. Br J Dermatol 2002;146:10061016.

-18 Finzi A, Mantovani L, Belisari A; Italian Association for Studies on Psoriasis: The cost of hospital-related care of patients with psoriasis in Italy based on the AISP study. J Eur Acad Dermatol Venereol 2001;15:320-324.

-19 Stern RS, Nijsten T, Feldman SR, Margolis DJ, Rolstad T: Psoriasis is common, carries a substantial burden even when not extensive, and is associated with widespread treatment dissatisfaction. J Investig Dermatol Symp Proc 2004;9:136-139.

-20 Huerta C, Rivero E, Rodriguez LA: Incidence and risk factors for psoriasis in the general population. Arch Dermatol 2007; 143:1559-1565.
21 Gelfand JM, Troxel AB, Lewis JD, Kurd SK, Shin DB, Wang X, Margolis DJ, Strom BL: The risk of mortality in patients with psoriasis: results from a population-based study. Arch Dermatol 2007;143:1493-1499.

22 Nast A, Kopp IB, Augustin M, et al: Evidence-based (S3) guidelines for the treatment of psoriasis vulgaris. J Dtsch Dermatol Ges 2007;5:1-119.

23 Augustin M, Reich K, Reich C, Purwins S, Rustenbach SJ, Schäfer I, Radtke MA: Quality of psoriasis care in Germany - results of the national study PsoHealth 2007. J Dtsch Dermatol Ges 2008;6:640-645.

24 Schmid-Ott G, Künsebeck HW, Jäger B, Sittig U, Hofste N, Ott R, Malewski P, Lamprecht F: Significance of the stigmatization experience of psoriasis patients: a 1-year follow-up of the illness and its psychosocial consequences in men and women. Acta Derm Venereol 2005;85:27-32.

25 Schöffski O, Augustin M, Prinz J, Rauner K, Schubert E, Sohn S, Reich K: Costs and quality of life in patients with moderate to severe plaque-type psoriasis in Germany: a multicenter study. J Dtsch Dermatol Ges 2007;5: 209-219.

26 Augustin M, Wenninger K, Gieler U, Schroth MJ, Chren M, Kupfer K, Gieler U: German adaption of the 'Skindex-29' questionnaire on quality of life in dermatology: validation and clinical results. Dermatology 2004;209: 14-20.

27 Augustin M, Lange S, Wenninger K, Seidenglanz K, Amon U, Zschocke I: Validation of a comprehensive Freiburg Life Quality Assessment (FLQA) core questionnaire and development of a threshold system. Eur J Dermatol 2004;14:107-113.

28 Schaefer I, Rustenbach SJ, Zimmer L, Augustin M: Prevalence of skin disease in a cohor of 48,665 employees in Germany. Dermatology 2008;217:169-172.

29 Lecluse LLA, Naldi L, Stern RS, Spuls PI: National registries of systemic treatment for psoriasis and the European 'Psonet' initiative. Dermatology DOI: 10.1159/000183757.

30 Augustin M, Schäfer I, Campbell K, Gothe H, Höer A, Klesse M, Osowski U, Radtke M, Glaeske G: Approaches on the description of health provision based on secondary data of the statutory health insurances - the example psoriasis. 2008. www.egms.de/en/meetings/dkvf2008/08dkvf169.shtml.
31 Reich K, Krüger K, Mössner R, Augustin M: Epidemiology and clinical pattern of psoriatic arthritis in Germany: a prospective interdisciplinary epidemiological study of 1,511 patients with plaque-type psoriasis. $\mathrm{Br}$ J Dermatol, in press.

32 Augustin M, Krüger K, Radtke MA, Schwippl I, Reich K: Disease severity, quality of life and health care in plaque-type psoriasis: a multicenter prospective cross-sectional study in Germany. Dermatology 2008;216: 366-372.

-33 Augustin M, Gajur AI, Reich C, Rustenbach SJ, Schaefer I: Benefit evaluation in vitiligo treatment: development and validation of a patient-defined outcomequestionnaire. Dermatology 2008;217:101-106.

34 Gulliver W: Long-term prognosis in patients with psoriasis. Br J Dermatol 2008;159(suppl 2):2-9.

>35 Basra MK, Fenech R, Gatt RM, Salek MS, Finlay AY: The Dermatology Life Quality Index 1994-2007: a comprehensive review of validation data and clinical results. Br J Dermatol 2008;159:997-1035.

36 Hongbo Y, Thomas CL, Harrison MA, Salek MS, Finlay AY: Translating the science of quality of life into practice: what do dermatology life quality index scores mean? J Invest Dermatol 2005;125:659-664

37 Augustin M, Reich K, Radtke MA, Dierks C (eds): Quality of Life, Compliance and Empowerment in Psoriasis. Bremen, Uni-Med Science, 2007.

38 Finlay AY: Current severe psoriasis and the rule of tens. Br J Dermatol 2005;152:861867.

39 Augustin M: PsoNet - more health care quality through regional psoriasis networks. J Dtsch Dermatol Ges 2008;6:263-264.

40 Boehncke WH, Adebajo A, Cauli A, Nash P, Salvarani C, Kavanaugh AF: Initiative for quality in psoriasis and psoriatic arthritis. J Rheumatol 2008;35:1431-1433.

41 Salek S, Roberts A, Finlay AY: The practical reality of using a patient-reported measure in a routine dermatology clinic. Dermatology $2007 ; 215: 315-319$. 